\title{
Effectiveness of care for older people: a review
}

\author{
Christina R Victor, Irene Higginson
}

Older people - that is, those aged 65 and over - are the largest single group of people using health care services in Great Britain. In $1986-7$ in England $48 \%$ of all NHS expenditure was accounted for by those aged 65 and over, $17 \%$ by those aged $65-74,22 \cdot 7 \%$ by those aged $75-84$, and $8 \cdot 6 \%$ by those aged 85 and over. Average annual NHS expenditure per head was estimated at $£ 414$ for those aged $65-74, £ 926$ for those aged $75-84$, and $£ 1452$ for those aged 85 and over. ${ }^{1}$

Demographic forecasts for England and Wales predict an increase between 1991 and 2031 of $43 \%$ in those aged from $60-64$ (pensionable age) to 74 (from 5.8 million to 8.3 million) and of $237 \%$ in those aged 85 and over (from 0.8 million to 1.9 million). ${ }^{2}$ The 1991 census enumerated 11.6 million people in Great Britain aged 60 or over, with roughly 800000 being aged 85 or older. $^{2}$ These demographic trends imply that considerable pressure will be placed on the NHS. Against this background of potentially substantially increasing demand it is important that older people (and indeed other client groups) receive the most effective forms of care and treatment. In this paper we bring together evidence about the evaluation of health care for this important client group.

We can approach a review of the effectiveness of services for older people in two ways. We could review current knowledge about the types of health problems faced by older people such as stroke or dementia, or we could consider what is known about the different types of services used by older people such as continuing care or rehabilitation. From a public health purchasing perspective we considered that the second approach was appropriate because contracts are currently placed for specific services rather than conditions. This paper is part of a needs assessment for older people undertaken for a review of services provided for older people in an inner London health district. We reviewed work published about the effectiveness of the care of older people in seven main areas: $(a)$ health promotion and primary prevention; $(b)$ secondary and tertiary prevention; $(c)$ hospital discharge; $(d)$ rehabilitation; $(e)$ home care; $(f)$ continuing care; and $(g)$ palliative care. We recognise that this is not a comprehensive review. It does, however, include the main service areas concerned with the care and treatment of older people. In reviewing the evidence for the effectiveness of specific interventions we have concentrated on randomised controlled trials or comparative studies when available, but we have also had to consider evidence derived from descriptive and observational studies.

\section{Health promotion and primary prevention}

Health promotion and primary prevention aim at maintaining and promoting health and wellbeing. Prevention and reduction of physical and mental illness and disability are important elements of any health promotion strategy for older people, especially if the agency wished to ensure that older people could be maintained in their own homes in the community.

In the United Kingdom older people have been largely excluded, either implicitly or explicitly, from most activity concerned with the promotion of health in the community and from studies concerned with the identification of risk factors for specific diseases. This reflects a concern with the health problems of younger age groups - for example, HIV or smoking in schoolchildren. Too often age is equated with disease. $^{3}$ Such a concentration on health promotion issues affecting younger people may reflect an ageist attitude - that it is not worth investing in trying to improve the health of those aged over 60 . Studies which have examined the benefit of, for example, reducing the classic risk factors for cardiovascular disease (hypertension, blood lipid concentrations, smoking, weight, etc) have usually excluded from their sample people aged 60 and over. The Whitehall studies, on which much of our evidence for the efficacy of reducing risk factors for heart disease is based, included only people of working age. ${ }^{4}$ One exception to this general rule was the European study of hypertension, which showed the benefits of treating hypertension in those aged 60 and over. $^{6}$

Despite this relative neglect of the potential role of health promotion among older people, there is evidence that regular exercise ${ }^{78}$ (but not short bursts of exercise), ${ }^{9}$ weight control, ${ }^{6}$ eating a healthy diet, ${ }^{7}$ and smoking cessation are beneficial to older people and improve a range of outcome measures including both length and quality of life (table 1).

Studies of the effectiveness of health promotion and primary prevention are often confounded by the lack of information provided about the intervention undertaken, the precise nature of the population studied, and the cost effectiveness of the programmes. Additionally, a focus on primary prevention and health promotion requires action socially and politically to provide the context in which lifestyle changes will be made. Encouraging senior lecturer

Correspondence to: Dr Victor 
Table 1 Health promotion and primary prevention

\begin{tabular}{|c|c|c|}
\hline Intervention & Outcome & Reference \\
\hline Regular exercise & Improves length and quality of life & Davies, ${ }^{7}$ Department of Health ${ }^{8}$ \\
\hline Short bursts of exercise & Not effective and may reduce wellbeing & Ebrahim and Williams ${ }^{9}$ \\
\hline Weight control and healthy diet & $\begin{array}{l}\text { Being overweight or underweight increases mortality; weight } \\
\text { control improves length and quality of life }\end{array}$ & Davies $^{7}$ \\
\hline Reduced salt in diet & $\begin{array}{l}\text { May be helpful in middle and moderate old age, but there is } \\
\text { concern that in very frail elderly people it reduces food } \\
\text { intake, causing them to become underweight and at high } \\
\text { risk of fractures if they fall }\end{array}$ & Davies $^{7}$ \\
\hline Stopping smoking & $\begin{array}{l}\text { Prevents or reduces deterioration in coronary heart disease } \\
\text { and prevents stroke. Smoking is also known to be a risk } \\
\text { factor in osteoporosis. Reduction in risk from lung cancer } \\
\text { is found only if smoking is stopped for a long period - } \\
\text { therefore not practical in very old people }\end{array}$ & Davies, ${ }^{7}$ Department of Health ${ }^{8}$ \\
\hline Improved lighting at home & Reduces number of falls & Davies, ${ }^{7}$ Department of Health ${ }^{8}$ \\
\hline
\end{tabular}

older people to participate in, for example, leisure activities will produce few positive health outcomes if people cannot afford to participate.

\section{Secondary and tertiary prevention}

The traditional tripartite division of prevention into primary, secondary, and tertiary prevention is difficult to maintain when considering the health care needs of older people. For those in the eighth and ninth decades the distinction between early diagnosis (secondary prevention) and treatment of established disease to limit its health consequences (tertiary prevention) can become blurred.

Most surveys of older people resident in the community have identified the presence of medical conditions previously unknown to the general practitioner. ${ }^{10}$ Numerous studies have shown the ability of multidimensional assessment of older people to detect problems with vision, ${ }^{11}$ hearing, ${ }^{12}$ chewing, ${ }^{12}$ locomotion, ${ }^{12}$ and iatrogenic disease. ${ }^{13}$ When assessment is combined with follow up, improvements have been seen in functional status, ${ }^{6}$ reduced use of drugs, and decreased rates of admission to nursing homes ${ }^{14}{ }^{15}$ (table 2). Many of the early studies investigating multidimensional assessment of older people were observational in nature, thereby reducing the confidence which we may have in the results. Recent work indicates that the full benefit of multidimensional assessment seems to be confined to services where assessment is combined with long term follow up.

Iatrogenic disease is an important cause of both death and illness among older people. Some specific interventions to reduce iatrogenic disease have been tested. A randomised controlled trial showed that a letter from their general practitioner was highly effective in reducing benzodiazepine use among patients, including older people (the maximum age of patients in the study was 102). ${ }^{19}$

There is strong evidence establishing the proved benefits of a limited number of specific treatments for older people. These include the early detection and treatment of depression and other functional conditions, ${ }^{16}$ incontinence, ${ }^{17}$ and hypertension (at least up to the age of 80 years ${ }^{5}$ ), hip replacements, ${ }^{20}$ and coronary artery bypass surgery. ${ }^{21}$ Fibrinolytic treatment has been shown to reduce mortality in patients with suspected acute myocardial infarction. The use of this treatment in older patients remains contentious. A recent review of nine trials based on 58600 patients concluded, however, that fibrinolytic treatment was associated with excess mortality on days 0 and 1 (especially for older patients) but that this was outweighed by much larger benefits during days $2-35$. The authors concluded that

Table 2 Secondary and tertiary prevention

\begin{tabular}{|c|c|c|}
\hline Intervention & Outcome & Reference \\
\hline $\begin{array}{l}\text { Early detection and treatment } \\
\text { of depression }\end{array}$ & $\begin{array}{l}\text { Relieved within 3-6 weeks in } 70 \% \text {; delayed treatment has } \\
\text { poor prognosis }\end{array}$ & Meyers et al ${ }^{16}$ \\
\hline $\begin{array}{l}\text { Early detection and treatment } \\
\text { of incontinence }\end{array}$ & Curing or substantially ameliorating incontinence & Ousland $^{17}$ \\
\hline $\begin{array}{l}\text { Multidimensional assessment } \\
\text { including physical health, } \\
\text { functional ability, } \\
\text { psychological status, and } \\
\text { social support }\end{array}$ & $\begin{array}{l}\text { Better detection of and attention to problems of vision, } \\
\text { hearing, feet, chewing, locomotion, and mental state }\end{array}$ & Amery $e t a l^{6}$ \\
\hline $\begin{array}{l}\text { Geriatric/medicine of old age } \\
\text { assessment and follow up }\end{array}$ & $\begin{array}{l}\text { Improved diagnostic accuracy: improved placement location, } \\
\text { improved functional status, improved affect or cognition, } \\
\text { reduced number of prescribed treatments, decreased use } \\
\text { of nursing homes (especially if included with rehabilitation } \\
\text { unit or home visit team, or both), reduced use of acute } \\
\text { hospitals, reduced medical care costs, prolonged survival. } \\
\text { (The last three particularly are included with the home } \\
\text { visit team or home visiting services and rehabilitation) }\end{array}$ & Rubenstein $e t$ al ${ }^{14}$ Rubenstein ${ }^{15}$ \\
\hline \multirow[t]{2}{*}{ Treatment of hypertension } & $\begin{array}{l}\text { Reduces mortality from stroke and heart disease up to age of } \\
80 \text {. Not yet studied in people over } 80\end{array}$ & Marmot $^{5}$ \\
\hline & Is cost effective & Johannession $e t$ al $^{18}$ \\
\hline
\end{tabular}


this early hazard should not obscure the clear longer term beneficial effect on mortality in those receiving fibrinolysis. ${ }^{22}$

With age, the incidence of and mortality from cancer increases significantly. In Great Britain the two routine cancer screening programmes, for breast and cervical cancer, stop at the age of 65 . This cut off point was selected because little is known about the risks, benefits, and feasibility of screening older people. In particular it has been argued that uptake of such programmes would be low, thereby making them not cost effective. Clearly there is considerable need for further research examining the effectiveness of cancer screening among older people. However, the age limits for these screening programmes may be reevaluated in the light of increased life expectancy, the development of the health strategy Health of the Nation, and the aging of the cohorts of women brought up to expect the provision of cancer screening programmes. Education, changes in the design and promotion of screening services offering screening in primary care, and use of nurse practitioners are all factors which have been proved to increase the uptake of cervical and breast cancer screening. ${ }^{23-27}$

\section{Assessment of older people}

Comprehensive multidimensional assessment of older people is one of the cornerstones of the specialty of geriatric medicine. Such assessments may be undertaken either in the hospital or in the person's home.

Table 3 summarises the main benefits observed. Studies have consistently reported decreased mortality among those assessed and improved detection of medical conditions but, unfortunately, little impact on functional status. The use of services usually increases, but admissions to hospital and long term care may decrease. ${ }^{28-31}$
Many issues concerned with the home assessment of older people still require clarification. The cost-benefit aspects of this type of service have not been fully considered. The best method of providing the screening service - for example, by telephone or using health visitors or other trained health workers - has not been investigated. There is also no strong evidence to identify the age of the screened population at which such programmes may be most effective. ${ }^{32}$

\section{Discharge from hospital}

Older people are the principal client group of the secondary care sector. Admission to hospital may represent a major dislocation of the pattern of care being received by older people in the community and may be extremely disruptive to their social support networks. ${ }^{32}$ An extensive body of literature, which is largely descriptive in nature, has pointed to the short notice patients may receive of their impending discharge, the lack of information being given to patients about drugs prescribed to take home, the lack of involvement of carers, the lack of communication between the primary and secondary care sectors, and the failure of appropriate services to be provided once they return home ${ }^{33}$ (table 4). Another suggested result of poor discharge planning and aftercare is readmission to hospital. This perceived failure of current procedures for the discharge of older people prompted the Department of Health to send out a circular (HC(89)5) which sought to improve discharge planning for patients of all ages.

Good evidence to indicate the best ways of improving these obvious deficiencies is rather sparse (table 4). Descriptive studies have proposed setting up various hospital discharge and aftercare schemes and appointing discharge liaison nurses to facilitate early and

Table 3 Assessment

\begin{tabular}{|c|c|c|}
\hline Intervention & Outcome & Reference \\
\hline $\begin{array}{l}\text { Home assessment and referral } \\
\text { team }\end{array}$ & $\begin{array}{l}\text { Lower mortality, fewer hospital admissions, lower cost but } \\
\text { greater use of home services (patients over 75). }\end{array}$ & Hendriksen $e t a l^{8}$ \\
\hline $\begin{array}{l}\text { Home assessment by health } \\
\text { visitors }\end{array}$ & $\begin{array}{l}\text { Lower mortality, higher affect, and greater use of home } \\
\text { services in urban but not rural areas }\end{array}$ & Vetter $e t a l^{9}$ \\
\hline Home assessment teams & $\begin{array}{l}\text { Increased detection of disease and problems; } 23 \% \text { improved } \\
\text { after } 1 \frac{1}{2-2} \text { years }\end{array}$ & $\begin{array}{l}\text { Williamson et al } l^{10} \text { Lowther } e t \\
\text { al }^{30}{ }^{\text {Barber }}\end{array}$ \\
\hline
\end{tabular}

Table 4 Discharge

\begin{tabular}{lll}
\hline Intervention & Outcome & Reference \\
\hline Hospital discharge schemes & $\begin{array}{c}\text { A more timely and integrated service can provide } \\
\text { quick and high quality care to patients for a } \\
\text { short time after discharge but can overburden } \\
\text { and be expensive for social services }\end{array}$ & Neill and Williams ${ }^{34}$ \\
$\begin{array}{l}\text { Equip hospital discharge scheme organisers } \\
\text { with access to transport, access to rapid } \\
\text { supply of aids and home adaptations, } \\
\text { and means of identifying those at high } \\
\text { risk, by using indicators of unplanned } \\
\text { admission, living alone, being without } \\
\text { regular visitors in hospital }\end{array}$ & $\begin{array}{c}\text { Noth but recommended to identify those } \\
\text { with thest delays in discharge }\end{array}$ & Neill and Williams ${ }^{34}$ \\
$\begin{array}{l}\text { Homefinder service - to locate appropriate } \\
\text { placements for patients who require long } \\
\text { term institutional care within the private } \\
\text { sector }\end{array}$ & $\begin{array}{c}\text { Reduction in length of stay in medicine of old } \\
\text { age wards }\end{array}$ & Miskelly et al ${ }^{35}$ \\
\hline
\end{tabular}


less problematic discharge. A cautionary note was struck, however, by one comprehensive evaluation, which noted that the creation of liaison nurses may make things more rather than less complex. ${ }^{36}$ One randomised controlled trial by Townsend et al showed a $25 \%$ reduction in readmission rates among older people provided with a two week programme of community support. ${ }^{37}$ However, routine visiting after discharge by a health visitor did not reduce the number of readmissions. Provision of a special aftercare scheme did not facilitate early discharge among the intervention group. ${ }^{38}$

Several studies have drawn attention to the use of acute beds by patients awaiting placement in nursing home or long term care. Provision of a homefinder service dedicated to locating appropriate private sector long term care has been proposed as one way of reducing inappropriate use of acute hospital beds. ${ }^{35}$ Evaluations of this type of service are largely descriptive.

\section{Continuing care for older people}

Continuing or long stay care for older people is provided by four main agencies: the NHS, local authorities, private establishments, and the voluntary sector. Changes in the mix of provision of this type of care has resulted in a decrease in care in the public sector and a rise in care in the private sector. ${ }^{39}$

Although many negative comments and observations have been made about long stay care, there have been few attempts to evaluate the effectiveness of such care using rigorous scientific methods. Two randomised controlled trials have compared care provided in NHS long stay wards with that in NHS nursing homes (table 5).$^{4142}$ Both of these studies failed to detect any difference in functional ability or mortality between the two groups. Those in the nursing homes, however, were observed as having better quality of life and experience of care than their contemporaries in NHS hospitals. However, we should be cautious in inferring from these studies that all nursing homes necessarily provide care which is superior to that offered by the public sector.

\section{Home care of older people}

Current policy for the care of older people supports the substitution of community for institutional forms of provision. This policy rests on the assumption that community based care of dependent elderly people is more effective, provides a better quality of life, is cheaper than institutional forms of provision, and reflects the wishes of older people themselves. These assumptions have not been evaluated in well controlled trials. The cost of caring for people at home increases with disability and in some circumstances may be considerably more expensive than continuing care. For very frail people care at home may reproduce many of the negative features associated with institutional environments. Descriptive studies have reported that some old people who would otherwise have entered long stay hospital care can be maintained at home (table 6). However, many of the full implications and costs of such policies remain unclear.

\section{Rehabilitation}

Rehabilitation units that have been evaluated tend to receive patients who have been admitted for acute illness, and they have a specialist in medicine of old age. Studies of this type have shown improved functional status, a reduction in the number of drugs prescribed, and improved wellbeing for patients. A randomised control trial comparing an inpatient rehabilitation unit and conventional care found even greater benefits than earlier descriptive studies, reduced rates or

Table 5 Continuing care

\begin{tabular}{|c|c|c|}
\hline Intervention & Outcome & Reference \\
\hline $\begin{array}{l}\text { Nursing home with small homely } \\
\text { environments } v \text { hospital care }\end{array}$ & $\begin{array}{l}\text { Better quality in observational studies, though } \\
\text { evidence on mental and functional ability and } \\
\text { cost is varied }\end{array}$ & $\begin{array}{l}\text { Vetter, }^{40} \text { Bowling et al, }{ }^{41} \\
\text { Donaldson and Bond } \\
4243\end{array}$ \\
\hline Home $v$ hospital care & $\begin{array}{l}\text { Lower costs both for agency and social } \\
\text { opportunity costs but may be related to case } \\
\text { mix; few studies }\end{array}$ & Chalice, et $a l^{44}$ \\
\hline $\begin{array}{l}\text { Domus philosophy - small units of } \\
\text { permanent residential care, with a } \\
\text { multidisciplinary team for people with } \\
\text { dementia }\end{array}$ & Improved quality of care - shown by observation & Macdonald ${ }^{45}$ \\
\hline
\end{tabular}

Table 6 Home care

\begin{tabular}{lll}
\hline Intervention & Outcome & Reference \\
\hline Home care instead of institutional care & $\begin{array}{l}\text { Studies rather equivocal and few differences } \\
\text { found in terms of morbidity or satisfaction of } \\
\text { carers } \\
\text { Reduced use of hospital services and cost savings } \\
\text { for patients requiring short term care for } \\
\text { palliative care or after discharge }\end{array}$ & Anand $e t l^{46}$ \\
Hospital at home & $\begin{array}{l}\text { Case managers have a budget that represents two } \\
\text { thirds of the cost of inpatient care in a } \\
\text { residential home }\end{array}$ & In progress \\
$\begin{array}{l}\text { Case management project }-2 \cdot 5 \text { social } \\
\text { workers plus a multidisciplinary } \\
\text { community psychogeriatric team for } \\
\text { people with serious behavioural } \\
\text { disturbance or other problems }\end{array}$ & & \\
\hline
\end{tabular}


Table 7 Rehabilitation

\begin{tabular}{|c|c|c|}
\hline Intervention & Outcome & Reference \\
\hline $\begin{array}{l}\text { Inpatient rehabilitation unit (usually } \\
\text { accompanied by geriatric assessment) - } \\
\text { for frail elderly patients, usually after } \\
\text { acute admission }\end{array}$ & $\begin{array}{l}\text { Improved functional status, reduced number of } \\
\text { drugs prescribed, lower readmission to hospital } \\
\text { and lower use of nursing homes, improved } \\
\text { wellbeing }\end{array}$ & $\underset{\text { Balaban }^{52}}{\text { Rubenstein } e t}{ }^{14}{ }^{140}$ Liem et al, ${ }^{51}$ \\
\hline $\begin{array}{l}\text { Hospital assessment and rehabilitation for } \\
\text { chronically ill patients of } 55 \text { and over }\end{array}$ & $\begin{array}{l}\text { Improved emotional state and wellbeing but no } \\
\text { significant effects on readmission, functional } \\
\text { status, or cost }\end{array}$ & Balaban $^{52}$ \\
\hline
\end{tabular}

readmission to hospital and use of nursing homes, and improved wellbeing in the patients receiving rehabilitation. Studies of rehabilitation units have tended to concentrate on frail elderly patients. Studies of younger patients (around 55) with chronic disease tended to show lesser benefit. Rehabilitation of stroke, either in domiciliary or hospital based services, have shown benefits among elderly patients. ${ }^{47-49}$ (table 7)

\section{Palliative care}

Access to palliative care units is usually limited to patients who have cancer. Some evidence suggests that patients receiving palliative care from support teams and in hospices tend to be younger than the local district population of patients with cancer. ${ }^{53}$ The only randomised controlled trial of inpatient hospice care found some benefits for family members in terms of reduced anxieties and increased satisfaction but little difference in patient outcomes. This trial has been criticised, however, because patients received both conventional and hospice services in the hospice group. When compared with conventional hospital care, other studies have shown evidence of improved pain and control of symptoms, less use of invasive procedures and higher patient and carer satisfaction, better resolution of grief, and lower costs among hospice or palliative care units, which have staff trained in symptom management. Home support teams were able to increase the amount of time that patients spent at home, increase carer satisfaction, and in some cases lower costs (table 8).

Currently, there are few services that will offer palliative care to patients who have a progressive disease other than cancer. One American randomised control trial of a homecare service showed that patients with various diseases and their families benefited more from a homecare service than from conventional services in terms of symptom control and satisfaction (table 8). Patients in the home care group also spent more time at home and less in hospital than the control group. ${ }^{68}$ In the United Kingdom a consultant in medicine of old age has developed a ward that offers symptom control and palliative care. ${ }^{69}$ Also, palliative care support teams will increasingly accept patients who do not have cancer. ${ }^{66}$

\section{Conclusion}

Older people are the main consumers of the services provided by the NHS. The coming decades will see a considerable increase in the number and proportion of very old people. Health agencies may find this review useful in helping them to ensure that they purchase the most effective models of care and treatments. Yet, as we have said, knowledge of the effectiveness of the interventions and care given to older people is underdeveloped. Too few treatments or interventions given to older people have been evaluated. For example, how should screening services be organised? Who should do the screening, and who should be screened? Given that resources for health care are finite, this potential increase in demand for health care will be problematic unless more is known about the most effective and efficient ways of caring for older people.

Our far from comprehensive review shows that older people are often excluded from studies assessing the risk of disease or evaluating health care services or interventions. We suggest that in the future older people should not be excluded from such studies and that much work is needed to examine the effectiveness and efficiency of many of the services they use. The development of health care purchasing and rigorous needs assessment may stimulate such studies. If more is known about the care of older people purchasing agencies will benefit in that they will be able to allocate their resources judiciously. Such knowledge would also greatly benefit older people in that they would receive the most effective and most appropriate forms of care and treatment.

We thank Dr Leila Lessof for her helpful comments on the needs assessment.

Table 8 Palliative care

\begin{tabular}{|c|c|c|}
\hline Intervention & Outcome & Reference \\
\hline $\begin{array}{l}\text { Hospice } v \text { hospital for people } \\
\text { with cancer }\end{array}$ & $\begin{array}{l}\text { Best control of pain and symptoms, less use of invasive } \\
\text { procedures, higher patient and carer satisfaction, and } \\
\text { better resolution of carer's grief; some evidence of lower } \\
\text { cost but varies from unit to unit and is not found if } \\
\text { inpatient stay is protracted }\end{array}$ & $\begin{array}{l}\text { Kane et al, },^{54-56} \text { Hinton, }{ }^{57} \text { Mor } e t \\
\text { al, }{ }^{58} \text { Seale, }{ }^{59} \text { Higginson et al, }{ }^{60} \\
\text { Higginson and McCarthy, }{ }^{61} \\
\text { Parkes }{ }^{62-65}\end{array}$ \\
\hline Home care support teams & $\begin{array}{l}\text { More time spent at home, more people dying at home, and } \\
\text { increased carer satisfaction. Costs between one eighth and } \\
\text { one half of inpatient costs. Patients who lived alone or who } \\
\text { had frail carers were less likely to remain at home until } \\
\text { their death }\end{array}$ & $\begin{array}{l}\text { Higginson et al al, }{ }^{60} \text { Higginson and } \\
\text { McCarthy, }{ }^{61} \text { Parkes, }{ }^{65} \\
\text { Higginson, }{ }^{66} \text { Hinton }^{67}\end{array}$ \\
\hline
\end{tabular}



1 Victor CR. Health and health care in later life. Milton Keynes:

2 Office of Population Censuses and Surveys. 1991 Census: persons aged 60 and over. London: HMSO, 1993. (CEN 91 TM PEN.)

3 Lauder W. Health promotion in the elderly. British fournal of Nursing 1993;3:401-4

4 Brunner EJ, Marmot MG, White IR, et al. Gender and employment grade differences in blood cholesterol, apolipoproteins and haemostatic factors in the Whitehal II study. Atherosclerosis 1993;102:195-207.

5 Marmot $M$. Epidemiological approach to the explanation of social differentiation in mortality: the Whitehall studies. Soz Praventivmed 1993;38:271-9.

6 Amery A, Birkenhäger W, Brixko R, Bulpitt C, Clement D, Deruyttere $\mathrm{M}$, et al. Efficacy of antihypertensive drug
treatment according to age, sex, blood pressure and treatment according to age, sex, blood pressure and
previous cardiovascular disease in patients over the age of previous cardiovascular dis
60. Lancet 1986;ii:589-92.

7 Davies AMR. Prevention in the ageing. In: Kane RL, Grimley Evans J, Macfadyen D, eds. Improving the health of older people: a world view. Oxford: Oxford University Press, 1990:316-40.

8 Department of Health. On the state of public health for the year 1990. London: HMSO, 1991

9 Ebrahim S, Williams J. Assessing the effects of a health promotion programme for elderly people. $\mathcal{F}$ Public Health
Med 1992:14:199-205.

10 Williamson J, Stokoe IH, Fry S, et al. Old people at home: their unreported needs, Lancet $1964 ; \mathrm{i}: 111-20$.

11 World Health Organisation. The uses of epidemiology in the study of the elderly. Tech Rep 1984; No 706.

12 Heikken E, Waters EW, Brzezinski ZJ. The elderly in eleven countries. Copenhagen: World Health Organisation, 1988 (Public health in Europe, 21.)

13 Kane RL, Kane RA, Arnold SB. Prevention in the elderly: risk factor. Health Serv Res 1985;19:945-1006.

14 Rubenstein LZ, Rhee L, Kane RL. The role of geriatric assessment units in caring for the elderly: an analytic review. I Gerontol 1982;37:513-21.

15 Rubenstein LZ. The efficacy of geriatric assessment programmes. In: Kane RL, Grimley Evans J, Macfadyen $\mathrm{D}$, eds. Improving the health of older people: a world view. Oxford: Oxford University Press, 1990:417-39.

16 Meyers BS, Greenberg R, Mei-taiv. Delusional depression in the elderly. In: Schamoian CA, ed. Treatment of effective disorders in the elderly. Washington, DC: American Psychiatric Press, 1985:17-28.

17 Ousland JG. The efficacy of incontinence treatment. In: Kane RL, Grimley Evans J, Macfadyen D, eds. Improving the health of older people: a world view. Oxford: Oxford University Press, 1990:273-95.

18 Johannession $M$, Dahlof $B$, Londholm LH, Ekbom $T$, Hansson L, Oden A, et al. The cost-effectiveness of treating hypertension in elderly people - an analysis of the
Swedish trial in old patients with hypertension (STOP Hypertension). F Intern Med 1993;234:317-23.

19 Cormack MA, Sweeney KG, Hughes-Jones H, Foot GA Evaluation of an easy, cost-effective strategy for cutting benzodiazepine use in general practice. Br $\mathcal{F}$ Gen Pract 1994;44:5-8.

20 Jennett B. High technology medicine: benefits and burdens. London: Oxford University Press, 1986

21 Rahintoola SH, Grokemeir GL, Starr A. Ten year survival after coronary artery bypass surgery for angina in patients after coronary artery bypass surgery for angina

22 Fibrinolytic Therapy Trialists' (FTT) Collaborative Group. Indications of fibrinolytic therapy in suspected acute myocardial infarction: collaborative overview of early myocardial infarction: collaborative overview of early mortality and major morbidity results from all randomised trials of

23 Vogel VG, Bondy M, Ralabi S, Lord J, Laville EA. The Texas breast screening project. II. Demographics, risk profiles and health practices of participants. South Med $\mathscr{f}$ 1993:86:391-6.

24 King ES, Resch N, Rimer B, Lerman C, Boyce A, McGovern-Gorchov P. Breast cancer screening practices
among retirement community women. Prev Med 1993; 22:1-19.

25 Roetzheim RG, Van-Durme DJ, Brownlee HJ, Herold AH, Woodward LJ, Blair C. Barriers to screening among participants of a media promoted breast cancer screening participants of a media promoted breast canc

26 Mandelblatt J, Traxler M, Lakin P, Kanetsky P, Kao R. poor black women: who will participate? The Harlem poor black women: who will particip
Study Team. Prev Med 1993;22:20-33.

27 Mandelblatt J, Traxler M, Lakin P, Thomas L, Chauhan P, Matseoane S, et al. A nurse practitioner intervention to increase breast and cervical cancer screening for poor, elderly, black women. The Harlem Study Team. $\mathcal{F}$ Gen Intern Med 1993;8:173-8.

28 Hendriksen C, Lund E, Strongard E. Consequences of assessment and intervention among elderly people: a three year randomised control trial. BMF 1984;289:1522-4.

29 Vetter NJ, Jones DA, Victor CR. Effects of health visitors working with elderly patients in general practice:

30 Lowther CP, MacLoud RDM, Williamson J. Evaluation of early diagnostic services for the elderly. BMF 1970;iii: 275-7.

31 Barber JH. Screening and surveillance of the elderly at risk. Practitioner 1984;228:269-73.
32 Vetter NJ, Lewis PA, Llewellyn I. Is there a right age for case finding in elderly people? Age Ageing 1993;22:121-4.

33 Marks I. Seamless care or patchwork quilt? London: King's Fund Institute, 1994. (Research report 17.)

34 Neill J, Williams J. Leaving hospital: elderly people and their discharge to community care. London: HMSO, 1992

35 Miskelly F, Hearn V, Walton I, Johnson P. The homefinder service. Health Trends 1992;24(1):25-7.

36 Jowett S, Armitage S. Hospital and community liaison links in nursing: the role of the liaison nurse. Fournal of Advanced Nursing 1988;13:579-87.

37 Townsend J, Piper M, Frank AO, Dyer S, North WRS, Meade TW. Reduction in hospital readmission of elderly patients by a community based hospital discharge patients by a community based hospital discharge
scheme: a randomised controlled trial. BMF 1988;297: 544-7.

38 Willkins EI, Fitton F. Factors affecting early unplanned readmission of elderly patients to hospital. BMF 1988 ; 297:784-7.

39 Ebrahim S, Wallis S, Brittis S, Harwood S, Graham N. Long-term care for elderly people. Quality in Health Care 1993;2:198-203.

40 Vetter NJ. Purchasing long-term health care for elderly people. Long-term care for elderly people. London: HMSO, 1992.

41 Bowling A, Formby J, Grant K, Ebrahims S. A randomised controlled trial of nursing home and long-stay geriatric ward care for elderly people. Age Ageing 1991; 20:316-24.

42 Donaldson C, Bond J. Evaluation of continuing care accommodation for elderly people. Vol 6. Surveys of NHS hospital wards and nursing homes - views of relatives and hospital wards and nursing homes - views of relatives and
volunteers. Newcastle upon Tyne: University of Newvolunteers. Newcastle upon Tyne: Univer
castle, Healthcare Research Unit, 1989.

43 Donaldson C, Bond J. Cost of continuing care facilities in the evaluation of experimental National Health Service nursing homes. Age Ageing 1991;20:160-8.

44 Chalice D, Darton R, Johnson L, Stone M, Traske K. An evaluation of an alternative to long-stay hospital care for frail elderly patients. I. The model of care. Age Ageing 1991;20:236-44.

45 Macdonald A. Home-based case management and the domus models of long-term care of elderly people with dementia and behavioural problems. Long-term care for elderly people. Purchasing, providing and quality. London: HMSO, 1992.
Anand JK, Pryor GA, Morgan RT. Hospital at home. Health Trends 1989;21:46-8.

47 Gladman JR, Lincoln NB, Barer BH. A randomised controlled trial of a domiciliary and hospital based rehabilitation for stroke patients after discharge from hospital. F Neurol Neurosurg Psychiatry 1993;56:960-6.

48 Young J, Forster A. Day hospital and home physiotherapy for stroke patients: a comparative cost-effectiveness study. fR Coll Physicians Lond 1993;27:252-8.

49 Kalra L, Dale P, Crome P. Improving stroke rehabilitation. A controlled study. Stroke 1993;24:1462-7.

50 Rubenstein LZ, Josephson KR, Weiland GD, English PA Sayre JA, Kane RL. Effectiveness of a geriatric evaluation unit: a randomised controlled trial. $N$ Engl $f \mathrm{Med}$ 1984;311:1664-70.

51 Liem PH, Chernoff R, Carter WJ. Geriatric rehabilitation unit: a three-year outcome evaluation. $\mathcal{F}$ Gerontol 1986; 41:44-50.

52 Balaban DJ. Chronic care study: a randomised longitudinal study of patients with chronic diseases treated on a special care Health Economics, 1980.

53 Evans C, McCarthy M. Referral and survival of patients accepted by a terminal care support team. $\mathcal{f}$ Epidemiol Community Health 1984;38:310-4.

54 Kane RL, Klein SJ, Bernstein L, Rothenberg R. The role of hospice in reducing the impact of bereavement. 7 Chron Dis 1986;39:735-42.

55 Kane RL, Bernstein L, Wales J, Rothenberg R. Hospice effectiveness in controlling pain. $\mathcal{F} A M A$ 1985;253 2683-6.

56 Kane RL, Wales J, Bernstein L, et al. A randomised control trial of hospice care. Lancet $1984 ; \mathrm{i}: 890-4$

57 Hinton J. A comparison of places and policies for termina care. Lancet 1979;i:29-32.

58 Mor V, Greer DS, Castenbaum R. The hospice experiment. Baltimore: Johns Hopkins University Press, 1988.

59 Seale C. Death from cancer and death from other causes: the relevance of the hospice approach. Palliat Med 1991;5:12-9.

60 Higginson I, Wade A, McCarthy M. Palliative care: views of patients and their families. $B M \mathcal{F} 1990 ; 301$ : 277-81.

61 Higginson I, McCarthy $M$. Evaluation of palliative care: steps to quality assurance? Palliat Med 1989;3 267-74.

62 Parkes CM. Terminal care: evaluation of in-patient service at St Christopher's Hospice. Part I. Views of surviving spouse on effects of the service on the patient. Postgrad Med F 1979;55:517-22.

63 Parkes CM. Terminal care: evaluation of in-patient service at St Christopher's Hospice. Part II. Seif assessment of the effect of services on surviving spouses. Postgrad Med f 1979;55:523-7.

64 Parkes CM, Parkes J. Hospice versus hospital care - reevaluation after 10 years as seen by surviving spouses. Postgrad Med F 1984;60:120-4.

65 Parkes CM. Terminal care: evaluation of an advisory domiciliary service at St Christopher's hospice. Postgrad Med $\mathcal{F}$ 1980;56:685-9. 
66 Higginson I. Palliative care: a review of past changes and future trends. $\mathcal{F}$ Public Health Med 1993;15:3-8.

67 Hinton J. Which patients with terminal cancer are admitted from home care? Palliat Med 1994;8: mitted $197-210$
68 Zimmer JG, Groth-Juncker A, McCusker J. Effects of a physician-led home care team on terminal care. 7 Am
Geriatr Soc 1984;32:288-93. 69 Severs MP, Wilkins S. A hospi elderly people. Age Ageing 1991;20:361-4.

0 